\title{
Mechanical Properties and Microstructure of Mg-Al-Zn-Si-base Alloy
}

\author{
Yuan Guangyin ${ }^{1,2 *}$, Liu Manping ${ }^{1}$, Ding Wenjiang ${ }^{1}$ and Akihisa Inoue ${ }^{2}$ \\ ${ }^{1}$ Light Alloy Net Forming National Engineering Research Center, Shanghai Jiaotong University, Shanghai 200030, P.R.China \\ ${ }^{2}$ Institute for Materials Research, Tohoku University, Sendai 980-8579, Japan
}

\begin{abstract}
Magnesium alloys containing $\mathrm{Mg}_{2} \mathrm{Si}$ particles, as a promising low cost heat-resistant magnesium alloy for automobile engine applications, are attracting more and more attention of both material scientists and design engineers. Refinement of the Chinese script $\mathrm{Mg}_{2} \mathrm{Si}$ particle is a key for using this kind of alloy in sand casting or permanent mould casting. In the present work, a new type of heat-resistant magnesium alloy with low cost based on $\mathrm{Mg}-\mathrm{Al}-\mathrm{Zn}-\mathrm{Si}$ was developed. The effect of $\mathrm{Sb}$ addition and mischmetal (MM, a mixture of rare-earth, RE elements) microaddition to a $\mathrm{Mg}-\mathrm{Al}-\mathrm{Zn}-\mathrm{Si}$ alloy was investigated systematically from the viewpoints of microstructure, solidification process, mechanical properties and corrosion resistance. Microstructure observation revealed that Sb promoted the formation of fine polygonal type $\mathrm{Mg}_{2} \mathrm{Si}$ particles by providing the nucleation sites. Meanwhile, the grain sizes of modified $\mathrm{Mg}-\mathrm{Al}-\mathrm{Zn}-\mathrm{Si}-\mathrm{Sb}$ alloy are much finer than those of base alloy. Such improved microstructure brings about the significant improvement in tensile properties, toughness and creep resistance at elevated temperatures up to $200^{\circ} \mathrm{C}$, which is superior to or comparable to AE42 alloy. Moreover, the corrosion resistance of the new alloy is improved significantly by the MM microaddition.
\end{abstract}

(Received October 10, 2002; Accepted January 20, 2003)

Keywords: microstructure, mechanical properties, creep, corrosion resistance, magnesium alloy

\section{Introduction}

The growing demand for more fuel-efficient vehicles to reduce energy consumption and air pollution is a challenge for the automotive industry. The characteristic properties of magnesium alloys, low density, high strength stiffness to weight ratio, good damping capacity and diecastability, and recycling potential make it the ideal candidate for heavier materials (steel, aluminum) to reduce the weight of the car. The widely used magnesium alloys are $\mathrm{Mg}-\mathrm{Al}$ series, such as AZ91 and AM60, which have excellent castability, good mechanical properties at room temperature and low cost. However, the use of these magnesium alloys have been limited because of their poor heat resistance. ${ }^{1)}$ The previous investigation $^{2)}$ showed that the grain boundary sliding is an important part of the deformation mechanism at elevated temperatures in $\mathrm{Mg}-\mathrm{Al}$ based alloys. Therefore, to improve heat resistance in $\mathrm{Mg}-\mathrm{Al}$ based alloy, it seems an effective method to develop an alloy containing thermal stable intergranular phases, which can suppress the grain boundary sliding.

Recent studies indicate that addition of silicon to $\mathrm{Mg}-\mathrm{Al}-$ $\mathrm{Zn}$ alloy can achieve substantial increases in strength, toughness, etc. because $\mathrm{Mg}_{2} \mathrm{Si}$ formed by the addition of $\mathrm{Si}$ is the substantially effective strengthening particles, which exhibit a high melting temperature $\left(1085^{\circ} \mathrm{C}\right)$, low density $\left(1.9 \mathrm{~g} / \mathrm{cm}^{3}\right)$, high elastic modulus $(120 \mathrm{GPa})$, and a low thermal expansion coefficient $\left(7.5 \times 10^{-6 \circ} \mathrm{C}^{-1}\right) .{ }^{3)}$ However, the magnesium alloys containing $\mathrm{Si}$ are only limited to the diecasting, which has a rapid solid rate. $\mathrm{Mg}_{2} \mathrm{Si}$ compounds are prone to forming undesirable coarse Chinese script under conventional (or slower) solidification process. To use of magnesium alloys containing $\mathrm{Mg}_{2} \mathrm{Si}$ particles for sand casting or permanent mould casting, microstructural refine-

*To whom correspondence should be addressed. Current address: Inoue Laboratory, Institute for Materials Research, Tohoku University, Sendai 980-8577, Japan. E-mail: gyyuan@imr.tohoku.ac.jp ment should be achieved.

It has been reported that the as-cast microstructure of $\mathrm{Mg}$ alloys containing $\mathrm{Mg}_{2} \mathrm{Si}$ particles could be refined by $\mathrm{P}$ or $\mathrm{Ca}$ addition. ${ }^{4)}$ However, addition of phosphor can produce ignition and result in large quantity of sick smoke. In recent studies, ${ }^{5)}$ we found a more effective modifier of $\mathrm{Sb}$ than $\mathrm{Ca}$ in $\mathrm{Mg}-\mathrm{Al}-\mathrm{Zn}-\mathrm{Si}$ alloys. This paper reports the results of our preliminary experiments on the effects of $\mathrm{Sb}$ and $\mathrm{MM}$ simultaneous additions on the microstructural development, tensile strength, creep properties and corrosion resistance of $\mathrm{Mg}-5 \mathrm{Al}-1 \mathrm{Zn}-1 \mathrm{Si}$ alloy obtained by a permanent mould gravity casting process.

\section{Experimental Procedure}

Three alloys of which the compositions are listed in Table 1 were prepared in mild steel crucible under the protection of mixed gas of $\mathrm{CO}_{2} / 0.5 \% \mathrm{SF}_{6}$ using commercial stock. Tensile specimens with a gauge section of $15 \mathrm{~mm} \times$ $3.5 \mathrm{~mm} \times 2 \mathrm{~mm}$ were cut by electric spark machining from the bottom of ingots. Before testing all the specimens were solution heat-treated at $410^{\circ} \mathrm{C}$ for 10 hours, water quenched, and then aged at $200^{\circ} \mathrm{C}$ for 2 hours. All specimens for microstructural characterization were cut from the same positions on the ingots at $10 \mathrm{~mm}$ from the castings. Phases in the $\mathrm{Mg}-5 \mathrm{Al}-1 \mathrm{Zn}-1 \mathrm{Si}-\mathrm{X}$ alloys were analyzed by D/MaxIII A-12KW-Cu type XRD analyzer operated at $40 \mathrm{kV}$ and $120 \mathrm{~mA}$. Chemical analysis of the cast experimental alloys was performed by inductively coupled plasma (ICP). The electropolished samples were examined in a Philip-505 scanning electron microscope equipped with an energy dispersive X-ray spectrometer (EDS) to investigate the microstructures and second phases in the alloys. The grain size was determined using a line intercept method from a large number of non-overlapping measurements. 
Table 1 Chemical composition of the alloys (mass\%).

\begin{tabular}{|c|c|c|c|c|c|c|c|c|}
\hline Alloy code & $\mathrm{Mg}$ & $\mathrm{Al}$ & $\mathrm{Zn}$ & $\mathrm{Si}$ & $\mathrm{Sb}$ & $\mathrm{Mn}$ & $\operatorname{Re}$ & Grain size $(\mu \mathrm{m})$ \\
\hline $\mathrm{Mg}-5 \mathrm{Al}-1 \mathrm{Zn}-1 \mathrm{Si}$ & Bal. & 5.1 & 0.93 & 0.72 & - & - & - & $134 \pm 5$ \\
\hline $\mathrm{Mg}-5 \mathrm{Al}-1 \mathrm{Zn}-1 \mathrm{Si}-0.5 \mathrm{Sb}$ & Bal. & 5.0 & 0.95 & 0.70 & 0.45 & - & - & $68 \pm 5$ \\
\hline SJTU-HM1 & Bal. & 5.0 & 0.90 & 0.71 & 0.40 & - & 0.20 & $70 \pm 5$ \\
\hline AZ51 & Bal. & 5.0 & 0.80 & - & - & 0.20 & - & - \\
\hline AE42 & Bal. & 4.0 & - & - & - & 0.20 & 2.5 & - \\
\hline AZ91 & Bal. & 9.0 & 0.80 & - & - & 0.20 & - & - \\
\hline
\end{tabular}

\section{Results and Discussion}

\subsection{Microstructure}

The typical microstructure of the permanent mould cast $\mathrm{Mg}-5 \mathrm{Al}-1 \mathrm{Zn}-1 \mathrm{Si}$ based alloys is illustrated in Fig. 1. The microstructure consisted of Chinese-script type $\mathrm{Mg}_{2} \mathrm{Si}$ particles with interdendritic $\mathrm{Mg}_{17} \mathrm{Al}_{12}$ phases in matrix $(\alpha$ $\mathrm{Mg}$ ). When the as-cast specimens of the alloys were solution treated at $420^{\circ} \mathrm{C}$ for 10 hours (T4 condition), almost all of $\beta$ phase dissolved in the matrix and only Chinese-script type $\mathrm{Mg}_{2} \mathrm{Si}$ particle existed, as shown in Fig. 1(b), which indicated that $\mathrm{Mg}_{2} \mathrm{Si}$ has excellent thermal stability at elevated temperatures. With the addition of $\mathrm{Sb}$, two microstructural changes can be observed clearly: (1) morphology of the $\mathrm{Mg}_{2} \mathrm{Si}$ particles changed from coarse Chinese script shape to the fine polygonal shape. (2) the average size of grain decreased from 134 to $68 \mu \mathrm{m}$ (Figs. 1(b) and (c)). With the mischmetal microaddition to $\mathrm{Mg}-5 \mathrm{Al}-1 \mathrm{Zn}-1 \mathrm{Si}-0.5 \mathrm{Sb}$ alloy, the microstructure was not influenced obviously. The refinement may be due to the formation of lots of finely distributed polygonal type $\mathrm{Mg}_{2} \mathrm{Si}$ particles in the interface of liquid-solid former during solidification.

Figure 2 is the XRD results of $\mathrm{Mg}-5 \mathrm{Al}-1 \mathrm{Zn}-1 \mathrm{Si}-0.5 \mathrm{Sb}$ alloy. It is recognized peaks from $\mathrm{Mg}_{3} \mathrm{Sb}_{2}$ phase in the $\mathrm{Sb}$ containing alloys.

\section{2 $\mathrm{Mg}_{2} \mathrm{Si}$ phase heterogeneous nucleation}

Figure 3(a) shows micrograph of $\mathrm{Mg}_{2} \mathrm{Si}$ particles in the alloy containing $0.5 \mathrm{Sb}$. It is interesting that $\mathrm{Mg}_{2} \mathrm{Si}$ particles contain small particles inside (labeled "A"), which presumably act as nucleation sites for $\mathrm{Mg}_{2} \mathrm{Si}$ particles. Figure 3(a) shows a typical result on crystallization center in the Sbcontaining alloy obtained by magnified secondary electron image (SEI) of nucleus. Figure 3(b) shows the EDS spectra for the nucleus. It shows that the nucleus is enriched with $\mathrm{Mg}$, $\mathrm{Sb}$ and Si. Combining the information from XRD and EDS spectrum shows that the nature of nucleus is possible to be $\mathrm{Mg}_{3} \mathrm{Sb}_{2}$.

In classical nucleation theory, nucleating can be facilitated when the foreign particle displays a small lattice mismatch $(<6 \%)$ with the nucleating solid phase. ${ }^{6)}$ The results of calculation for some possible crystallographic orientations for $\mathrm{Mg}_{2} \mathrm{Si}$ nucleation on the $\mathrm{Mg}_{3} \mathrm{Sb}_{2}$ particles show that when the orientation relationship between $\mathrm{Mg}_{2} \mathrm{Si}$ phase and $\mathrm{Mg}_{3} \mathrm{Sb}_{2}$ phase is $(0001)_{\mathrm{Mg}_{3} \mathrm{Sb}_{2}} \|(111)_{\mathrm{Mg}_{2} \mathrm{Si}}$, the planar disregistry is the lowest $(5.1 \%){ }^{5}{ }^{5}$ Therefore, $\mathrm{Mg}_{3} \mathrm{Sb}_{2}$ can act as the heterogenerous nucleation for the $\mathrm{Mg}_{2} \mathrm{Si}$ phase by this orientation relationship.

\subsection{Solidification process of $\mathbf{M g}-\mathrm{Al}-\mathrm{Zn}-\mathrm{Si}$-base alloys}

Figure 4 shows a typical cooling curve for the $\mathrm{Mg}-5 \mathrm{Al}-$ $1 \mathrm{Zn}-\mathrm{X}$ based alloys under a cooling rate of $0.5^{\circ} \mathrm{C} / \mathrm{s}$. From the curves of solidification, the following information could be obtained: the practical temperature of the liquid metal at the moment of entry to the mold was $648^{\circ} \mathrm{C}$ and $621^{\circ} \mathrm{C}$ respectively, which was measured with a high sensitivity thermocouple. The wall of mold cavity chilled the liquid metal, causing the temperature of the liquid metal to rapidly drop. A little platform appeared in the curve at about $616^{\circ} \mathrm{C}$ for AZ51 and $606^{\circ} \mathrm{C}$ for SJTU-HM1 (The liquidus temperature of SJTU-HM1 is lower by $10^{\circ} \mathrm{C}$ than that of AZ51, which may be beneficial to the castability). With the decrease of temperature, the liquid metal starts to solidify. Owing to the high melting point of $\mathrm{Mg}_{2} \mathrm{Si}$ particles, the $\mathrm{Mg}_{2} \mathrm{Si}$ primarily precipitated. Followed by the onset of $\operatorname{Mg}(\alpha)$ formation, and then the further growth of $\mathrm{Mg}_{2} \mathrm{Si}$ phase and $\operatorname{Mg}(\alpha)$ phase and ends at $407^{\circ} \mathrm{C}$ (another platform, as arrowhead shown in Fig. 4), which is actually the non-equilibrium eutectic temperature for $\mathrm{L} \rightarrow \mathrm{Mg}(\alpha)+\mathrm{Mg}_{17} \mathrm{Al}_{12}$, forming the divorced eutectic structure of $\left[\mathrm{Mg}(\alpha)+\mathrm{Mg}_{17} \mathrm{Al}_{12}\right]$ as shown in Fig. 1(a).

\subsection{Mechanical properties}

The mechanical properties of the alloys with and without $\mathrm{Sb}$ and microaddition of RE are compared in Table 2. It can be seen that $\mathrm{Sb}$ and $\mathrm{RE}$ microaddition to the alloy (SJTUHM1) resulted in beneficial influence on improving the mechanical properties. It shows that the Sb- and REcontaining alloys have improved yield strength, ultimate tensile strength, elongation and apparent fracture toughness over the base alloy. It is obvious that the improvement of tensile strength was ascribed to three aspects: (1) small grain strengthening, (2) the change of morphology of $\mathrm{Mg}_{2} \mathrm{Si}$ from Chinese-script type to polygonal type, since long cracks can easily nucleate along the interface between Chinese-script $\mathrm{Mg}_{2} \mathrm{Si}$ particles and $\mathrm{Mg}$ matrix, and (3) the dispersion strengthening of fine particles $\left(\mathrm{Mg}_{2} \mathrm{Si}\right.$ and $\left.\mathrm{Mg}_{3} \mathrm{Sb}_{2}\right)$.

In addition, owing to its high melting point $\left(1228^{\circ} \mathrm{C}\right)$ of those $\mathrm{Mg}_{3} \mathrm{Sb}_{2}$ particles which can not act as nucleus of $\mathrm{Mg}_{2} \mathrm{Si}$ in $\mathrm{Mg}-5 \mathrm{Al}-1 \mathrm{Zn}-1 \mathrm{Si}$ are also effective strengthening phases for $\mathrm{Mg}$ alloy application at elevated temperatures, ${ }^{7)}$ which may be contributed to the improvement of tensile strength at elevated temperatures.

\subsection{Creep behavior}

Figure 5 is several typical creep strain vs. time curves obtained from the constant-load and constant-temperature test $\left(200^{\circ} \mathrm{C} / 50 \mathrm{MPa}\right)$ for the four kinds of alloys. The 

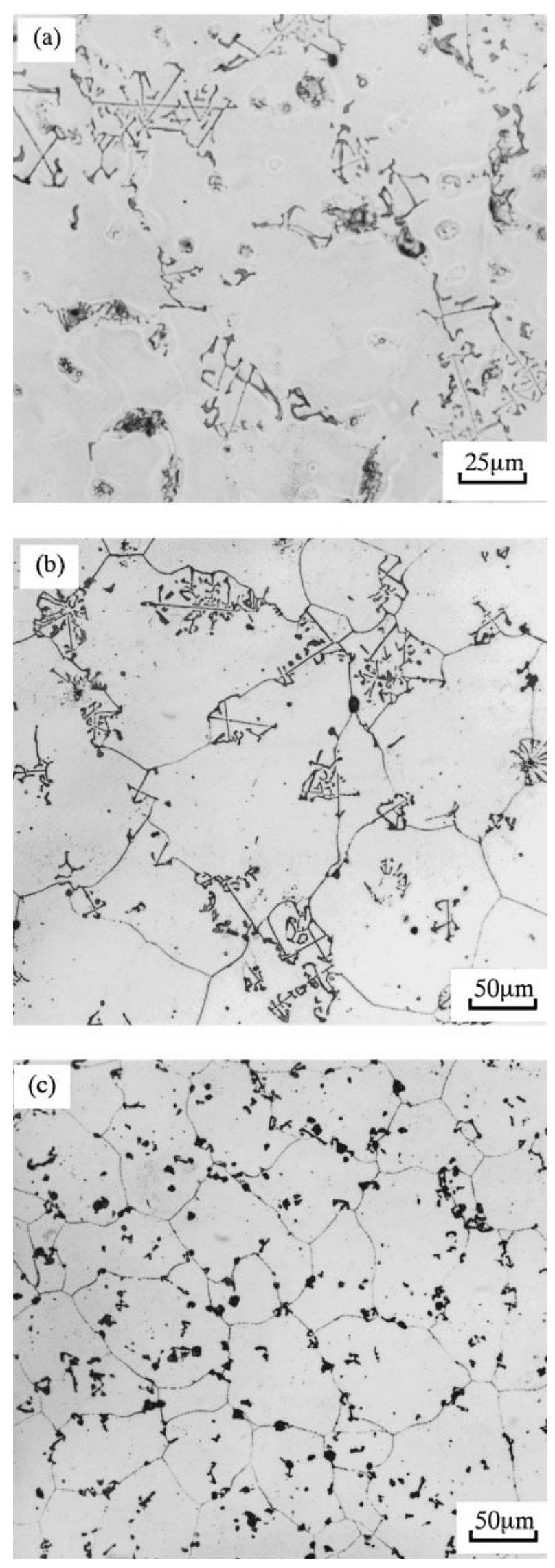

Fig. 1 Optical micrographs showing the effect of $\mathrm{Sb}$ addition on the microstructure of alloys; (a) as-cast $\mathrm{Mg}-5 \mathrm{Al}-1 \mathrm{Zn}-1 \mathrm{Si}$ alloy, (b) solution heat-treated $\mathrm{Mg}-5 \mathrm{Al}-1 \mathrm{Zn}-1 \mathrm{Si}$ alloy, (c) solution heat-treated $\mathrm{Mg}-5 \mathrm{Al}-$ $1 \mathrm{Zn}-1 \mathrm{Si}-0.5 \mathrm{Sb}$ alloy.

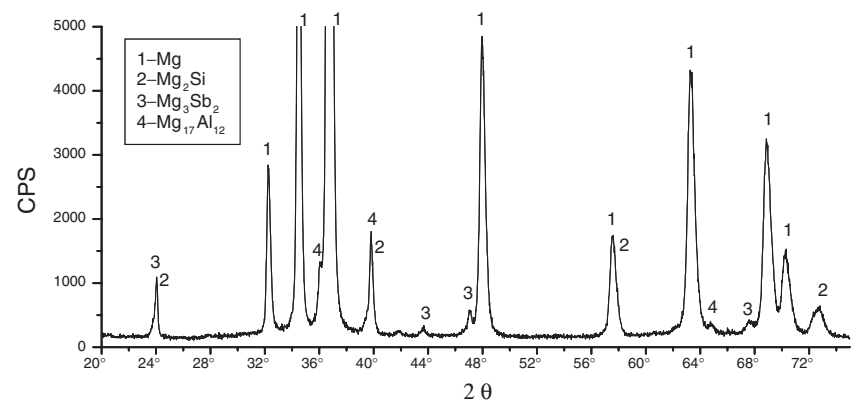

Fig. 2 X-ray diffraction patterns of as-cast Mg-5Al-1Zn-1Si-0.5Sb alloy.
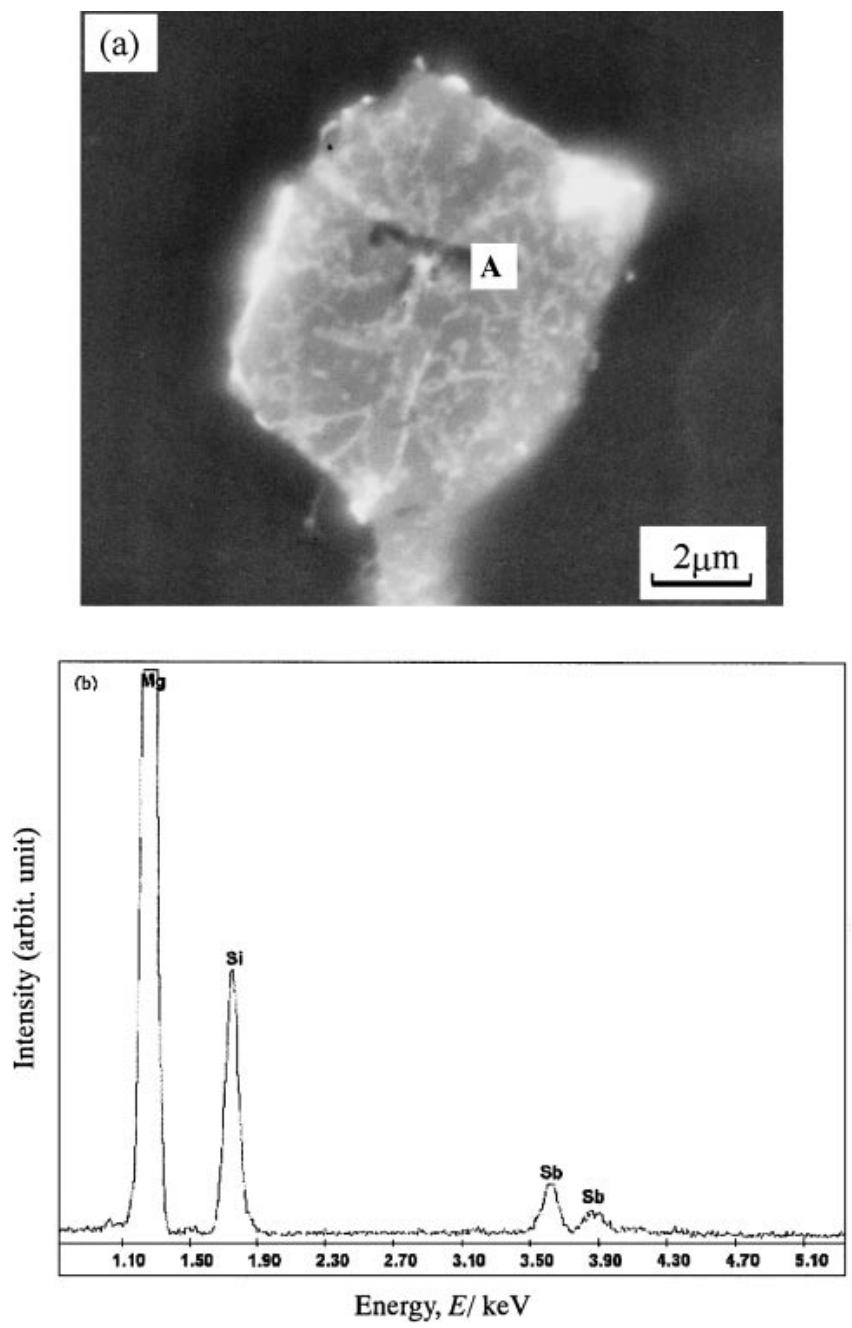

Fig. 3 Crystallization nuclei observing shows (a) SEI of $\mathrm{Mg}_{2} \mathrm{Si}$ particles in permanent mould cast $\mathrm{Mg}-5 \mathrm{Al}-1 \mathrm{Zn}-1 \mathrm{Si}-0.5 \mathrm{Sb}$ alloy (b) EDS spectrum from the nucleus area ' $A$ ' in (a).

simultaneous additions of $\mathrm{Sb}$ and mischmetal (MM) to $\mathrm{Mg}-$ $5 \mathrm{Al}-1 \mathrm{Zn}-\mathrm{Si}$ alloy reduced the steady state creep rate significantly. Moreover, the creep strain for the alloys after 100 hours decreased from $5.2 \%$ for $\mathrm{Mg}-5 \mathrm{Al}-1 \mathrm{Zn}-1 \mathrm{Si}$ to $2.6 \%$ for SJTU-HM1, even lower than that of AE42 (2.7\%). It showed that tensile creep property of the newly developed SJTU-HM1 alloy is better than that of AE42 alloy, which is the benchmark creep-resistant magnesium die casting alloy for automobile powertrain application. 

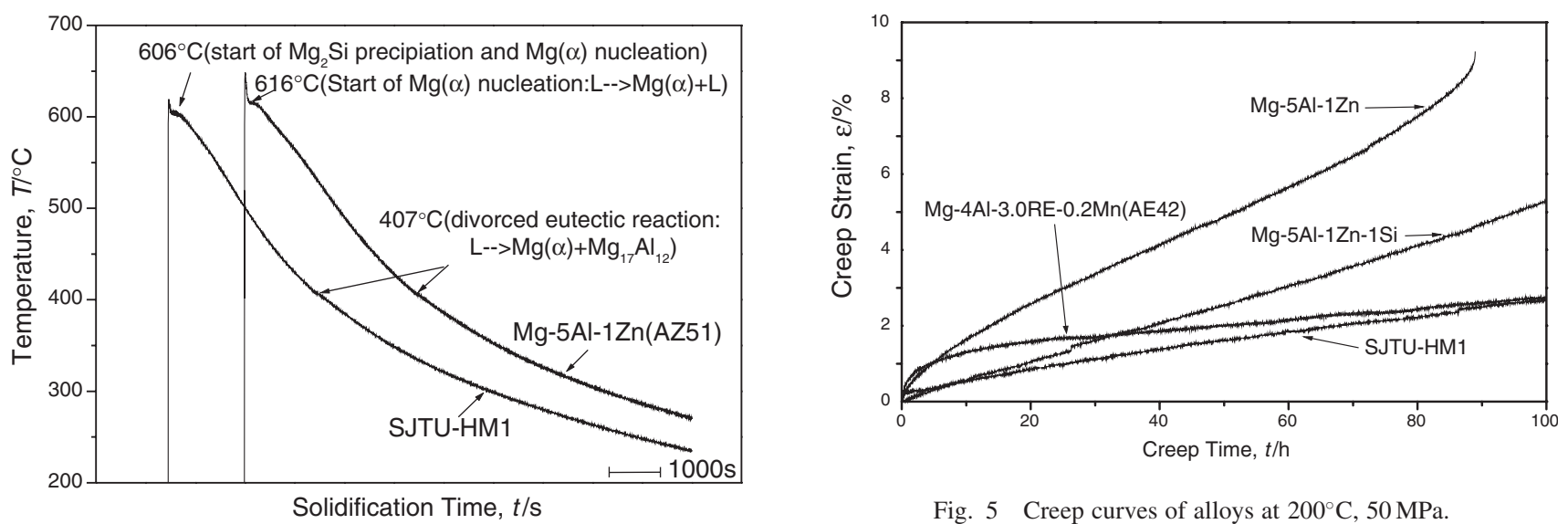

Fig. 5 Creep curves of alloys at $200^{\circ} \mathrm{C}, 50 \mathrm{MPa}$.

Fig. 4 Solidification cooling curves for alloys studied.

Table 2 Mechanical properties of permanent mould-cast $\mathrm{Mg}-\mathrm{Al}-\mathrm{Zn}-\mathrm{Si}-\mathrm{X}$ alloys.

\begin{tabular}{|c|c|c|c|c|c|c|c|}
\hline \multirow[b]{2}{*}{ Alloy } & \multicolumn{3}{|c|}{ RT tensile } & \multicolumn{3}{|c|}{$150^{\circ} \mathrm{C}$ tensile } & \multirow{2}{*}{$\begin{array}{c}\text { Apparent fracture } \\
\text { toughness } \\
A_{\mathrm{k}}(\mathrm{J})\end{array}$} \\
\hline & $\begin{array}{c}\text { Ulti. } \\
(\mathrm{MPa})\end{array}$ & $\begin{array}{l}\text { Yield. } \\
(\mathrm{MPa})\end{array}$ & $\begin{array}{c}\text { Elong. } \\
(\%)\end{array}$ & $\begin{array}{c}\text { Ulti. } \\
(\mathrm{MPa})\end{array}$ & $\begin{array}{l}\text { Yield. } \\
(\mathrm{MPa})\end{array}$ & $\begin{array}{c}\text { Elong. } \\
(\%)\end{array}$ & \\
\hline $\mathrm{AE} 42$ & 202 & 97 & 12 & 165 & 91 & 22 & 20 \\
\hline AZ91 & 234 & 110 & 3 & 175 & 96 & 20 & 15 \\
\hline
\end{tabular}

\subsection{Corrosion resistance properties}

Figure 6 shows the salt spray corrosion test result of the alloys. Si shows an adverse effect on corrosion properties. Single addition of $\mathrm{Sb}$ shows a similar effect like Si. On the other hand, with both additions of Sb and MM microaddition, SJTU-HM1 shows higher corrosion resistance than those of AZ51 and AE42 alloys. This showed that Misch metal (Ce, $\mathrm{La}, \mathrm{Nd}, \mathrm{Pr}$ ) improved the corrosion resistance for $\mathrm{Mg}-\mathrm{Al}$ based alloys in chloride solutions. The solubility of rare earths in the magnesium matrix is limited in the presence of aluminum, but the intermetallic Al-RE phase formed is electrochemically passive and does not affect the corrosion rate much ${ }^{8)}$ The high corrosion resistance of the STJU-HM1 appears to be related to a certain positive synergism of aluminum and RE elements in the aluminum rich zones along

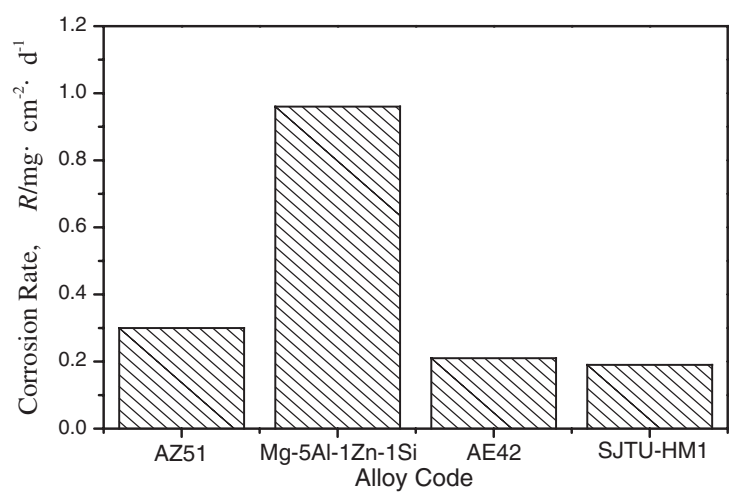

Fig. 6 Corrosion rate compared with standard die casting alloys. the grain boundaries, impeding the propagation of localized corrosion attack. The improved passivity of SJTU-HM1 under the conditions is possibly due to the enrichment of trace amounts of RE in the oxide film. Further investigation is under way.

\section{Summary}

Microstructure and mechanical properties and corrosion resistance for the developed SJTU-HM1 alloy were investigated and summarized as follows:

(1) Addition of $\mathrm{Sb}$ was found to be efficient in refining the microstructure of the $\mathrm{Mg}-5 \mathrm{Al}-1 \mathrm{Zn}-1 \mathrm{Si}$-base alloy. The morphology of $\mathrm{Mg}_{2} \mathrm{Si}$ particles changed from coarse Chinese-script shape to small polygonal type. The modification mechanism of $\mathrm{Sb}$ is the formation of the polygonal type $\mathrm{Mg}_{2} \mathrm{Si}$ particles nucleate from $\mathrm{Mg}_{3} \mathrm{Sb}_{2}$ particles.

(2) Refined microstructure in the modified alloy by simultaneous additions of $\mathrm{Sb}$ and mischmetal results in significant improvement in tensile properties and toughness, creep resistance at high temperatures as compared to the base alloy of $\mathrm{Mg}-5 \mathrm{Al}-1 \mathrm{Zn}-1 \mathrm{Si}$. The mechanical properties at room temperature are similar to or better than those of AZ91 alloy and the high temperature properties are even better than those of AE42 alloy.

(3) With simultaneous additions of $\mathrm{Sb}$ and mischmetal, the corrosion resistance of the Si-containing Mg alloy is improved significantly and even better than that of AE42 alloy. 


\section{Acknowledgements}

One of the authors (Yuan Guangyin) would like to thank the Japanese Society for the Promotion of Science (JSPS) for providing support to publish the present work.

\section{REFERENCES}

1) P. Humble: Mater. Forum. 21 (1997) 45-56.

2) Yuan Guangyin, Wang Qudong and Ding Wenjiang: J. Mater. Sci. 37 (2002) 127-132.

3) G. H. Li, H. S. Gill and R. A. Varin: Metall. Trans. A. 24A (1993) 2383
2387.

4) J. J. Kim, D. H. Kim, K. S. Shin and N. J. Kim: Scr. Mater. 41 (1999) 333-340.

5) G. Y. Yuan, Z. L. Liu, Q. D. Wang and W. J. Ding: Mater. Lett. 56 (2002) 53-58.

6) B. L. Bramfft: Metall. Trans. 6 (1971) 1258-1263.

7) Yuan Guangyin, Sun Yangshan and Ding Wenjiang: Scr. Mater. 43 (2000) 1009-1013.

8) O. Lunder and K. Nisancioglu: Progress in the understanding and prevention of corrosion, The 10th European Corrosion Congress, ed. by J. M. Costa and A. D. Mercer, (The Institute of Material, London, 1993) Vol. 1, pp. 1249-1253. 